\section{Causes of African famine}

SiR-Brian Perry ${ }^{1}$ stresses the need for constructive analysis and critical review of the causes of African famine, cites the opinion of Sinclair and Fryxell ${ }^{2}$ that overgrazing around artificial water holes in semi-arid areas is a major cause of desertification and climatic deterioration and concludes that the improvement of the environment must involve not only technical, but also social and political factors. I believe that his analysis is correct, but fear that social and political considerations are likely to be more intractable than purely technical problems.

The root cause of the problem is ecological $^{3}$ and can be overcome only by a far-reaching socio-economic revolution among the populations affected. The value systems of rural African communities are still largely those appropriate at the turn of the century, when most people were nomadic pastoralists or subsistence farmers practising shifting cultivation. Modern medicine and hygiene, and the suppression of tribal wars, led to great demographic change, with populations increasing fivefold or more in a few generations ${ }^{4}$.

The common feature of civilizations is not a value system but an administrative framework which allows the accumulation of agricultural surpluses and their distribution in time of famine, which can be viewed as behavioural adaptations to ecological pressures. A common factor has been the development of cities, which removed people from the land and formed a market for farmers, thus shifting the basis of the economy from subsistence to exchange.

Sufficient food for all the people of Africa could be produced by the practices already in use in those countries with developed agricultural sectors. The obstacle is the innate conservatism of the peasants, in contrast with fishermen in the area, who readily adopt new methods, probably because their product is perishable and must therefore be exchanged so that they are conceptually conditioned to a market economys.

People will produce goods surplus to their own requirements only if they are suitably rewarded by either spiritual satisfaction, disposable income or the avoidance of punishment. The last is generally unacceptable under a liberal value system, which leaves income as the only practicable incentive. Unfortunately, money alone is not sufficient, for it has no value unless it can be converted into goods or services considered desirable by the recipient. The lack of opportunity for such trade is the major disincentive to rural development in Africa. It may be significant, in this context, that Malawi, which is surrounded by Mozambique, Tanzania and Zambia, all of which have experienced shortages, has consistently produced a surplus of food. The difference is that in Malawi, education, which is universally perceived as desirable, is contingent on the payment of school fees. The provision of such services from government revenues alone is insufficient to ensure development of the economy.

The problem is thus socio-economic rather than technical, and it is in this area that research is most urgently needed. I feel that the key lies in the development of rural retail trade and consider it significant that countries such as Kenya, Zimbabwe and South Africa, all of which have been afflicted by drought, have been selfsufficient in food and usually have a surplus. They have in common a relatively well developed private sector producing consumer goods, coupled with good rural communications and well established trading centres.

I suggest that agricultural development projects should make provision also for training and for construction and loan capital for retail trade as well as for production. This would provide a local trading nucleus which would be an outlet for cash earnings and would serve to provide a local incentive within the project area, rather than in a remote town. It is fallacious to argue that such activity should be left to local entrepreneurs because, to a great extent, they lack the necessary capital or experience.

While this solution might conflict with some nationally cherished ideas of interdependence within the community and independence from external investment, I feel that it is only by adopting more liberal economic policies and specifically by encouraging the local production of consumer goods and the development of a rural distribution system, that the problem can be overcome and rural populations be brought fully into the economy.

56 St Margaret's Road,

Lowestoft NR32 4HT, UK

1. Perry, B. Nature 319, 183 (1986).

Krebs, J.R. \& Coe, M.J. Nature 317, 13-14 (1985)

3. Sinclair, A.R.E. \& Fryxell, J.M. Can. J. Zool. 63, 987 - 994 (1985).

4. Malawi Statistical Yearbook, 1977 (Government Printer, Zomba).

5. Eccles, D.H. Fishing News International, April 1985, 46-

\section{South Africa}

SIR-Bender et al. (Nature 319, 532; 1986) support the banning of South Africans from the World Archaeological Congress at Southampton and criticize your leading articles on the subject. Although they admit the existence of other repressive governments, they believe that South Africa should be singled out for two reasons. The first is the view of men who think more of words than of what is happening in the real world. The Gulag is not institutionalized, nor are the death squads that operate in Latin American countries, nor are the mass slaughters that take place constantly in the Middle East. It follows plainly, at least to your correspondents, that archaeologists from these countries should be welcomed at Southampton. The logic of the argument escapes us.

The second reason given for excluding South African academics also involves some arcane dialectics. There are, say Bender et al. " "historical moments" when repressive governments become unstable and when outside pressure, such as an academic boycott, "may have some effect", presumably in reforming them or destroying them. It is patently true that repressive governments are subject to "historical moments" when they become highly unstable; many of the dictatorships of South America are in precisely this state now, as are Uganda and several other countries in Africa, and half of the Middle East. Also, we all remember when Soviet tanks were required to preserve the governments of Hungary and of Czechoslovakia. As for Poland, its "historical moment" seems to be continuous. Bender et $a l$. are interestingly unforthcoming about banning participants from any of these countries. On the contrary, as representatives of developing countries and of Eastern Europe they will be especially welcome. Again, we fail to follow the reasoning.

At the end of the letter we are asked to state " . . . what it is that you are asking us to tolerate". The answer is simple: the presence at an international conference of about two dozen archaeologists most of whom oppose apartheid. What is more, they do so in South Africa where - unlike University College London - it takes courage.

Microbiology Unit,

J. Mandelstam

G.A. HARRISON
Department of Biological Anthropology, E.T. HALL

Research Laboratory of Archaeology,

The University, Oxford, UK

\section{Too colourful}

SIR-Vera Rich's report on the Chinese response to hydroengineering works on the Yangtse River (Nature 319, 13; 1986) became a bit too colourful. The river with the gorges should not be equated with the Huang He (Yellow River).

Hematology Service,

STEPHEN H. EMBury

Building 100, Room 263,

San Francisco General Hospital,

San Francisco,

California 94110, USA 